\title{
Operational experiences, military role conceptions, and their influence on civil-military relations
}

\author{
Christoph Harig ${ }^{1 *}$ (1), Nicole Jenne ${ }^{2}$ (1) and Chiara Ruffa ${ }^{3}$ (it) \\ ${ }^{1}$ Institute of International Relations, Technische Universität Braunschweig, Germany, ${ }^{2}$ Institute of Political Science, Pontificia \\ Universidad Católica de Chile, Santiago, Chile and ${ }^{3}$ Swedish Defence University, Stockholm, Sweden \\ ${ }^{*}$ Corresponding author. Email: c.harig@tu-braunschweig.de
}

(Received 9 April 2021; accepted 19 October 2021; first published online 23 November 2021)

\begin{abstract}
A considerable amount of research within security studies has explored the military's increasingly diverse and multifaceted tasks. However, this debate has been disconnected from the literature on civil-military relations to the effect that we still lack knowledge about how and why these operational tasks have consequences for the relations between the armed forces, civilian authorities, and society at large. In order to provide for a better understanding of these effects, this introduction to the Special Issue debates the concept of operational experiences to capture how the military's routine activities affect the equilibria, logics, and mechanisms of civil-military relations. The article then provides an overview of the Special Issue's six contributions, whose diverse and global perspectives shed light on different aspects of the relationship between military missions and the military's roles in society and politics. Among other factors, they highlight role conceptions - the military's shared views on the purpose of the institution - as crucial in shaping the dynamic relation between what the military does and what place it occupies within the state and society. The article concludes by describing potentially fruitful areas of future research.
\end{abstract}

Keywords: Civil-Military Relations; Military Missions; Operational Experiences; Role Conceptions; Military Professionalism

\section{Introduction}

It is well known that militaries today do much else and much more than fighting interstate wars. Despite the trope that soldiers were mostly trained to 'break things and kill people', ${ }^{1}$ armed forces across the globe engage in a range of different missions including community support, fighting organised crime and terrorism, peacekeeping, policing, infrastructure development, as well as humanitarian aid and disaster relief. More recently, militaries have also been widely active in responding to the COVID-19 pandemic by setting up mobile hospitals, enforcing containment measures, fabricating face masks, and in some cases even engaging in epidemiological research. ${ }^{2}$ Scholars have widely acknowledged the multidimensionality of militaries' tasks as well as the tensions and difficulties arising from it, mainly from an organisational perspective. ${ }^{3}$ Already in the

\footnotetext{
${ }^{1}$ Kimberly Marten, 'Statebuilding and force: The proper role of foreign militaries', Journal of Intervention and Statebuilding, 1:2 (2007), pp. 231-47 (p. 242).

${ }^{2}$ Nina Wilén, 'The military in the time of COVID-19: Versatile, vulnerable, and vindicating', PRISM Feature, 9:2 (2021), pp. 21-33; Jessica Kirk and Matt McDonald, 'The politics of exceptionalism: Securitization and COVID-19', Global Studies Quarterly, 1:3 (2021), available at: \{https://doi.org/10.1093/isagsq/ksab024\}. See also Yagil Levy, 'The people's army “enemising" the people: The Covid-19 case of Israel', European Journal of International Security, this Special Issue.

${ }^{3}$ Charles C. Moskos, John Allen Williams, and David R. Segall (eds), The Postmodern Military: Armed Forces after the Cold War (Oxford, UK: Oxford University Press, 2000); Peter Neuteboom and Joseph Soeters, 'The military role in filling the security gap after armed conflict: Three cases', Armed Forces \& Society, 43:4 (2017), pp. 711-33.

(c) The Author(s), 2021. Published by Cambridge University Press on behalf of the British International Studies Association. This is an Open Access article, distributed under the terms of the Creative Commons Attribution licence (https://creativecommons.org/licenses/by/4.0/), which permits unrestricted re-use, distribution, and reproduction in any medium, provided the original work is properly cited.
} 
classical work of Morris Janowitz and Charles C. Moskos, the idea of the combat-oriented, total and greedy institution - understood as an organisation that puts high demands on its members in terms of time, allegiances and commitment - clashed with the notion of a constabulary multifaceted organisation. ${ }^{4}$ In other words, operations of various kinds have been acknowledged to have direct effects on the military organisation and its members.

Notwithstanding the recognition that militaries do much more than combat, how those different kinds of missions shape civil-military relations has remained either underspecified or understood in a deterministic way. In general, the dominant distinction has been between external and internal missions. ${ }^{5}$ External military missions have usually been portrayed as beneficial for civilian supremacy as they prompt civilians to exercise control and keep the armed forces occupied outside a state's territory. This argument has been developed based on evidence from operations regarding national defence, combat, as well as UN peacekeeping. ${ }^{6}$ Similarly, military sociologists have mostly understood external combat as a 'conventional mission'. Accordingly, the armed forces are suitably prepared for combat but would have to learn to adapt to other tasks. Conversely, internal missions are typically seen as problematic for civil-military relations, since they allow military leaders to interfere in domestic politics. ${ }^{8}$ Yet, the focus on conventional military missions and the dichotomous understanding of external vs internal operations do not capture accurately what the military actually does and consequently, how this affects civil-military relations. ${ }^{9}$ Additionally, a sprawling literature on military learning and adaptation examines operations and conditions for organisational change. While these studies often acknowledge political conditions as important for military learning, their focus lies on perfecting doctrine and tactics during military operations rather than on the consequences these operations have for civilmilitary relations. ${ }^{10}$

We see potential in bringing together the literature about military missions and tasks, on the one hand, and about civil-military relations, on the other. This Special Issue asks an overarching question: how does the experience of and in military missions shape civil-military relations? The contributions adopt diverse approaches to explore and develop arguments on the logics, mechanisms, and processes that connect specific operational experiences to civil-military dynamics. They

\footnotetext{
${ }^{4}$ Charles C. Moskos, 'UN peacekeepers: The constabulary ethic and military professionalism', Armed Forces \& Society, 1:4 (1975), pp. 388-401; Morris Janowitz, The Professional Soldier: A Social and Political Portrait (New York, NY: The Free Press of Glencoe, 1960); Mady Wechsler Segal, 'The military and the family as greedy institutions', Armed Forces \& Society, 13:1 (1986), pp. 9-38; Erving Goffman, Asylums: Essays on the Social Situation of Mental Patients and Other Inmates (New York, NY: Anchor Books, 1961).

${ }^{5}$ For an early criticism of this simplistic dichotomy, see David Pion-Berlin and Craig Arceneaux, 'Decision-makers or decision-takers? Military missions and civilian control in democratic South America', Armed Forces \& Society, 26:3 (2000), pp. 413-36.

${ }^{6}$ Michael C. Desch, Civilian Control of the Military: The Changing Security Environment (Baltimore, MD: Johns Hopkins University Press, 1999); Deborah L. Norden, 'Keeping the peace, outside and in: Argentina's UN missions', International Peacekeeping, 2:3 (1995), pp. 330-49.

${ }^{7}$ Christopher Dandeker and James Gow, 'Military culture and strategic peacekeeping', Small Wars \& Insurgencies, 10:2 (1999), pp. 58-79; Claus Kold, 'New operations - new attitudes? Are soldiers' attitudes influenced by the objectives of peace operations?', Journal of International Peacekeeping, 17 (2013), pp. 46-73.

${ }^{8}$ Larry L. Watts, Whose Professionalism? Separating the Institutional Roles of the Military \& Police (Camberley: UK Defence Academy Research \& Assessment Branch, 2001).

${ }^{9}$ See David Kuehn and Yagil Levy, 'Theorizing threats, militarization, and civilian control', in David Kuehn and Yagil Levy (eds), Mobilizing Force: Linking Security Threats, Militarization, and Civilian Control (New York, NY: Lynne Rienner Publishers, 2021), pp. 223-43.

${ }^{10}$ Sergio Catignani, 'Coping with knowledge: Organizational learning in the British Army?', Journal of Strategic Studies, 37:1 (2014), pp. 30-64; Theo Farrell and Terry Terriff, The Sources of Military Change: Culture, Politics, Technology (Boulder, CO: Lynne Rienner, 2002); Evan A. Laksmana, 'Threats and civil-military relations: Explaining Singapore’s "trickle down” military innovation', Defense and Security Analysis, 33:4 (2017), pp. 347-65; Raphael D. Marcus, 'Military innovation and tactical adaptation in the Israel-Hizballah conflict: The institutionalization of lesson-learning in the IDF', Journal of Strategic Studies, 38:4 (2015), pp. 500-28; Anit Mukherjee, 'Fighting separately: Jointness and civil-military relations in India', Journal of Strategic Studies, 40:1-2 (2017), pp. 6-34.
} 
deal with several related questions, such as: How does the military adapt or refuse to adapt to missions it is reluctant about? To what extent do missions that are highly visible to the public change the military's role within the state and society? How does the military change its selfimage vis-à-vis civilian authorities and society due to different missions?

To answer these questions, this introductory article lays out an analytical approach with two conceptual components: operational experiences and role conceptions. Operational experiences are the social processes of militaries experiencing and giving meaning to a variety of tasks and activities during military missions that are conducted over a certain amount of time with a given stated objective by a significant share of its personnel. The understanding of operational experience builds on recent work that has problematised how new types of operations shape specific kinds of civil-military relations. ${ }^{11}$ Specifically, we use the concept of operational experiences to capture how the military deals with diverse and multifaceted operations. Operational experiences potentially shape the military's direct preferences for certain types of missions in various ways. For instance, successful combat operations will reinforce the use of those strategies and tactics that led to victory. Similarly, operations that enhance public prestige (as in disaster relief) and other possibilities to claim additional resources may receive greater military support. In turn, experiences of defeat or other negative consequences from operations can convince commanders that certain types of missions are undesirable and should therefore be avoided. ${ }^{12}$

In less immediate ways, operational experiences are also likely to shape the military's identity, culture, and professional ideals, which all affect how the military positions itself $v i s-\grave{a}$-vis the civilian 'other'. Some operational experiences turn into memories deeply ingrained and transmitted across generations of soldiers. ${ }^{13}$ Other, more recent ones will define how members of the military collectively continue to navigate the organisation they belong to. ${ }^{14}$ Uniformed personnel continuously live operational experiences by putting orders into practice and by making sense of them both individually and collectively. From this perspective, analysing operational experiences allows us to better understand what the military makes of formally assigned roles and core functions and how it adapts to them as they develop. As this Special Issue demonstrates, operational experiences matter in terms of how the military understands its relationship with decision-makers and society at large.

As the second conceptual component, the Special Issue highlights the concept of role conceptions as an analytical tool to study the relationship between operational experiences and civilmilitary relations. A role conception is the 'shared view, shared within one service or shared by all the services, regarding the proper purpose of the military organization and of military power in international relations'. ${ }^{15}$ Role conceptions are contingent on a military's historical experience and therefore vary significantly. To illustrate, armies with a strong focus on external defence and/or significant experience in expeditionary warfare might consider it inappropriate to use scarce resources for secondary tasks such as internal law enforcement. To other militaries, however, a historical engagement in socioeconomic development, or even the political affairs

\footnotetext{
${ }^{11}$ Eyal Ben-Ari and Eran-Jona Meyyal, 'Hybrid conflicts, multiple logics, and organizational transitions: Military relations with local civilians', Res Militaris, 4:2 (2014), pp. 1-14; Cornelia Baciu, Civil-Military Relations and Global Security Governance: Strategy, Hybrid Orders and the Case of Pakistan (London, UK: Routledge, 2021).

${ }^{12}$ For more details on how these preferences later shape eventual dissent against political demands, see Risa Brooks and Peter Michael Erickson, 'The sources of military dissent: Why and how the U.S. military contests civilian decisions about the use of force', European Journal of International Security, this Special Issue.

${ }^{13}$ For instance, French soldiers developed negative memories about their experience in Lebanon with the Multinational Force in 1982-4, during which they suffered many casualties: Chiara Ruffa, 'What peacekeepers think and do: An exploratory study of Ghanaian, Korean, French and Italian soldiers in the UN mission in Lebanon', Armed Forces and Society, 40:2 (2014), pp. 199-225; Eric Sangar, 'The weight of the past(s): The impact of the Bundeswehr's use of historical experience on strategy-making in Afghanistan', Journal of Strategic Studies, 38:4 (2015), pp. 411-44.

${ }^{14}$ Elin Gustavsen, 'The construction of meaning among Norwegian Afghanistan veterans', International Sociology, 31:1 (2016), pp. 21-36.

${ }^{15}$ Pascal Vennesson, Fabian Breuer, Chiara de Franco, and Ursula C. Schroeder, 'Is there a European way of war? Role conceptions, organizational frames, and the utility of force', Armed Forces and Society, 35:4 (2009), pp. 628-45 (p. 630).
} 
of their country, lead to role conceptions in which internal involvement is conceived as the military's proper purpose. Seen within the wider context of civil-military relations, variations in historical experience also lead to diverging preferences regarding the operational profiles of the armed forces among politicians and citizens. By bringing together contributions from different parts of the globe, the Special Issue underlines the value of role conceptions for studying civilmilitary relations.

Building on military sociology scholarship, the concept of role conception is nested within the broader concept of military professionalism. Its value lies in that role conception is more precise, concrete, and able to capture a fundamental constitutive component of military life. It refers to the self-understanding of the military's core roles only as opposed to an understanding held by a more diffuse group including different national elites and the population as a whole. As such, role conceptions allow us to trace - in a more focused way - both the different logics and mechanisms through which operational experiences are made sense of by the military and, in turn, whether and how these experiences then affect role conceptions. While a range of factors potentially influences how operational experiences shape civil-military relations - history, culture, material resources, and recruitment considerations, among others - the generally little-used concept of role conception emerged inductively as a key and recurring common denominator across the contributions to this Special Issue. The authors allude to role conceptions from different perspectives and to different degrees, though taken together their findings promise new insights and ways for future analysis.

In the remainder of this article, we discuss key concepts and debates on the drivers of civilmilitary relations and reflect upon how the Special Issue contributes to ongoing academic debates. We then present the core argument of the Issue and introduce the six contributions, which together represent a plurality of theoretical, methodological, and geographical perspectives on the connections between different kinds of operational experiences, role conceptions, and civilmilitary relations. In a last step, we outline avenues for future research.

\section{Civil-military relations and military missions}

This Special Issue adopts a broad view on civil-military relations that captures the complex relationships between three actors: the military, civilian elites, and society. These relationships are understood as a dynamic phenomenon negotiated in day-to-day interactions and policymaking. Although this conceptualisation is now fairly well established in the literature, ${ }^{16}$ it is worth reflecting on its analytical leverage by contrasting it with the long dominant, narrower focus on the position of civilian authorities $v i s-\grave{a}$-vis the military leadership.

The view on civil-military relations as a rather static distribution of power between civilian and military elites underlies most studies that focus on visible military interventions in politics, predominantly coups. ${ }^{17}$ For instance, some theories explain civil-military relations with the nature of threats facing a particular state. Accordingly, external threats reduce military involvement in domestic politics and likewise the risk of coups. ${ }^{18}$ Conversely, high levels of internal threats or intrastate conflict increase the likelihood of the military playing a prominent political role. ${ }^{19}$ Michael C. Desch argues that the most stable type of civil-military relations with the strongest

\footnotetext{
${ }^{16}$ See David Pion-Berlin and Rafael Martínez, Soldiers, Politicians, and Civilians (Cambridge, UK: Cambridge University Press, 2017).

${ }^{17}$ See, for example, Magnus Lundgren, 'Backdoor peacekeeping: Does participation in UN peacekeeping reduce coups at home?', Journal of Peace Research, 55:4 (2017), pp. 508-23; Erica De Bruin, 'Preventing coups d'état: How counterbalancing works', Journal of Conflict Resolution, 62:7 (2018), pp. 1433-58.

${ }^{18}$ Michael C. Desch, Civilian Control of the Military: The Changing Security Environment (Baltimore, MD: Johns Hopkins University Press, 1999).

${ }^{19}$ Peter B. White, 'The perils of peace: Civil war peace agreements and military coups', The Journal of Politics, 82:1 (2019), pp. 104-18.
} 
civilian control is precisely when the level of external threat is high and the level of internal threat is low. ${ }^{20}$ Along parallel lines, large- $\mathrm{N}$ quantitative studies have examined the effect of international conflict on the risk of coups. ${ }^{21}$ For instance, Curtis Bell and Jun Koga Sudduth find that ongoing civil war makes coup attempts more likely and that this likelihood is greatest when the fighting is close to the capital. ${ }^{22}$ Still, it is now widely acknowledged that the exclusive focus on coups fails to grasp the far more nuanced reality of civil-military relations. ${ }^{23}$ As one scholar of coups puts it: 'given the uncertainty of success, both sides [the military and government] have an incentive to avoid a coup', which makes its absence hardly an indicator of military subordination to civilian control. ${ }^{24}$ While easy to code for statistical analysis, ultimately this rather rare, exceptional, and extreme form of intervention tells us little about the varied and complex interactions of the military with politics and society.

The military's agency and political influence beyond visible interventions such as coups are well documented. As early as in the 1960s, Samuel E. Finer argued that the armed forces have a range of subtler options at their disposal to influence government policies that do not require taking over power. For instance, they can simply refuse to obey orders. ${ }^{25}$ Others have demonstrated how the armed forces can exercise tutelary power and contest democratic governance by means of institutional prerogatives. ${ }^{26}$ The military can find numerous ways, overt and covert, to influence and contest political decision-making to the extent that it can significantly constrain the options of democratically elected politicians. ${ }^{27}$ Even in the United States, the country that is widely seen as having achieved Samuel Huntington's ideal of objective civilian control with a clear division between a subordinate, 'professional' military, on the one hand, and the civilian sphere, on the other, ${ }^{28}$ heads of military service branches have frequently exercised veto powers and compelled governments to compromise with the armed forces. ${ }^{29}$ An important reason for this, in Peter D. Feaver's view, is that the military as agent often has different preferences than their civilian principals. ${ }^{30}$ Processes of contestation and bargaining - in both democratic and autocratic

\footnotetext{
${ }^{20}$ Michael C. Desch, Civilian Control of the Military: The Changing Security Environment (Baltimore, MD: Johns Hopkins University Press, 1999), p. 14.

${ }^{21}$ Caitlin Talmadge, The Dictator's Army: Battlefield Effectiveness in Authoritarian Regimes (Ithaca, NY: Cornell University Press, 2015); Deniz Aksoy, David B. Carter, and Joseph Wright, 'Terrorism in dictatorships', The Journal of Politics, 74:3 (2012), pp. 810-26.

${ }^{22}$ Curtis Bell and Jun Koga Sudduth, 'The causes and outcomes of coup during civil war', Journal of Conflict Resolution, 61:7 (2017), pp. 1432-55.

${ }^{23}$ Aurel Croissant, David Kühn, Paul Chambers, and Siegfried O. Wolf, 'Beyond the fallacy of coup-ism: Conceptualizing civilian control of the military in emerging democracies', Democratization, 17:5 (2010), pp. 950-75.

${ }^{24}$ White, 'The perils of peace: Civil war peace agreements and military coups', p. 105.

${ }^{25}$ Samuel E. Finer, The Man on Horseback: The Role of the Military in Politics (London, UK: Pall Mall, 1962).

${ }^{26}$ Alfred Stepan, Rethinking Military Politics: Brazil and the Southern Cone (Princeton, NJ: Princeton University Press, 1988).

${ }^{27}$ Aurel Croissant, Tanja Eschenauer, and Jill Kamerling, 'Militaries' roles in political regimes: Introducing the PRM data set', European Political Science, 16 (2017), pp. 400-14; Kristen A. Harkness, 'Military loyalty and the failure of democratization in Africa: How ethnic armies shape the capacity of presidents to defy term limits', Democratization, 24:5 (2017), pp. 80118. See also Brooks and Erickson, 'The sources of military dissent'.

${ }^{28}$ Risa A. Brooks, 'Integrating the civil-military relations subfield', Annual Review of Political Science, 22:1 (2019), pp. 37998; José A. Olmeda, 'Escape from Huntington's labyrinth: Civil-military relations and comparative politics', in Thomas C. Bruneau and Florina Cristiana Matei (eds), The Routledge Handbook of Civil-Military Relations (Abingdon, UK: Routledge, 2013), pp. 61-76.

${ }^{29}$ Andrew J. Bacevich, 'Elusive bargain: The pattern of U.S. civil-military relations since World War II', in Andrew J. Bacevich (ed.), The Long War: A New History of U.S. National Security Policy Since World War II (New York, NY: Columbia University Press, 2007), pp. 207-64 (p. 219).

${ }^{30}$ Peter D. Feaver, Armed Servants: Agency, Oversight and Civil-Military Relations (Cambridge, MA: Harvard University Press, 2003).
} 
systems - thus shape civil-military relations. ${ }^{31}$ However, only recently scholars have begun to examine what civilian control and military autonomy means on a daily basis. ${ }^{32}$

The implications of new missions on civil-military relations have been addressed in the literature in a rather compartmentalised form according to the internal/external dichotomy described above. However, dividing missions according to the location of deployment is too simplistic and fails to capture important variances. Literature drawing on experiences from Latin America, sub-Saharan Africa, and parts of Asia has highlighted that the military's involvement in internal missions has in fact varying effects on civilian control. ${ }^{33}$ After all, it must be assumed that the military's internal use to fight crime or insurgencies by means of force has different effects on civil-military relations than domestic humanitarian aid and disaster relief operations. Studies on peacekeeping further illustrate the problem. Reflecting the traditional reasoning, some postulate that sending the military abroad to serve in the interest of collective security positively affects civil-military relations. ${ }^{34}$ Others have argued against this view, ${ }^{35}$ pointing to the paradox that peacekeepers often perform exactly those functions the military is not meant to perform in their home state if a healthy civil-military relations equilibrium is to be maintained, such as guarding internal order and public security. Recent studies have highlighted how the similarities between domestic counterinsurgency missions and peace enforcement tasks in UN peace operations have increased the role of some militaries in guaranteeing public security, together with their political power. ${ }^{36}$ It thus appears that certain kinds of operational experiences magnify preexisting conditions in civil-military relations. By-and-large, the consequences of operational experiences vary according to different contexts of civil-military relations.

In order to provide a more suitable analytical understanding of changes in civil-military relations that were brought about by military missions, we introduce the concept of operational experience. As we describe in the next section, this entails a move in two steps. First, we unpack the general categories of internal vs external missions into the broader sets of tasks, roles, and operations. ${ }^{37}$ Secondly, these are understood not only as operations or tasks and roles in practical terms, but also in terms of how the military experiences and draws lessons from them.

\section{Operational experience as a key determinant of civil-military relations}

A focus on the ordinary, recurring aspects of civil-military relations should also include examinations of what the military is routinely doing and how these activities are understood and reflected upon by members of the armed forces. In line with recent efforts of 'putting the military back into civil-military relations', ${ }^{38}$ the Special Issue therefore places particular emphasis on

\footnotetext{
${ }^{31}$ Brooks, 'Integrating the civil-military relations subfield', p. 209.

${ }^{32}$ Philippe Lagassé and Stephen M. Saideman, 'When civilian control is civil: Parliamentary oversight of the military in Belgium and New Zealand', European Journal of International Security, 4:1 (2019), pp. 20-40.

${ }^{33}$ Abel Esterhuyse, 'The domestic deployment of the military in a democratic South Africa: Time for a debate', African Security Review, 28:1 (2019), pp. 3-18; Beatrice Jauregui, 'Civilised coercion, militarised law and order: Security in colonial South Asia and the blue in green global order', in Marleen Easton (ed.), Blurring Military and Police Roles (The Hague, the Netherlands: Eleven International Publishing, 2010), pp. 57-77; David Pion-Berlin, Military Missions in Democratic Latin America (Basingstoke, UK: Palgrave Macmillan, 2016).

${ }^{34}$ Rafa Martínez and Marién Durán, 'International missions as a way to improve civil-military relations: The Spanish Case (1989-2015)', Democracy and Security, 13:1 (2017), pp. 1-23.

${ }^{35}$ Philip Cunliffe, 'From peacekeepers to Praetorians: How participating in peacekeeping operations may subvert democracy', International Relations, 32:2 (2018), pp. 218-39; Julián González Guyer and Nicole Jenne, 'Controlling Blue Berets: The consequences of political neglect in the case of Uruguay's participation in peacekeeping', Armed Forces \& Society, 47:3 (2021), pp. 435-56; Christoph Harig, 'Learning to fight in UN peacekeeping', Defence Studies, 20:2 (2020), pp. 39-60.

${ }^{36}$ Kai-Michael Kenkel, 'Stability abroad, instability at home? Changing UN peace operations and civil-military relations in Global South troop contributing countries', Contemporary Security Policy, 42:2 (2021), pp. 225-40.

${ }^{37}$ Kuehn and Levy, 'Theorizing threats, militarization, and civilian control'.

${ }^{38}$ Thomas C. Bruneau, 'Putting the military back into civil-military relations', Latin American Research Review, 56:1 (2021), pp. 251-9.
} 
understanding how operational experiences shape interactions between society, political elites, and the armed forces.

To say that missions affect civil-military relations is all but a novel claim. Scholarship within comparative politics, security studies, as well as strategic and military studies has explored the paradoxes of military organisations traditionally devoted to combat and yet often tasked with other missions. ${ }^{39}$ However, most existing studies have either sought to explain how militaries adapt and innovate to perform new tasks or examined the implications of new missions for national and international security, as well as for the military's combat-readiness. ${ }^{40}$ By contrast, much less attention has been paid to the consequences of these ordinary tasks and roles for civilmilitary relations. ${ }^{41}$ Examples of the latter are Eyal Ben-Ari and Eran-Jona Meyyal, who explore different kinds of military 'institutional logics', such as an anti-terror logic, one of border policing and humanitarian assistance, and how these influence the military's relations with local civilians. ${ }^{42}$ Cornelia Baciu's work, too, highlights the importance of studying military activities and their ramifications for both the military's self-understanding and civil-military relations. Identifying a set of military functions that can be observed in hybrid orders where democratic and non-democratic actors coexist, Baciu explores how international donors and nongovernmental organisations can drive a shift in 'cultural conceptions about the military's role in society', which may then trigger an unwanted military response. ${ }^{43}$ Set aside these more recent examples, the role played by the experience of operations is dealt with in scholarship from the 1990s, which debated the link between what were then new missions for the US military and a supposed crisis in US civil-military relations. ${ }^{44}$ This Special Issue differs from these earlier studies in that it introduces and explicitly focuses on the concept of operational experience as an analytical tool. This allows us to assess how the armed forces make sense of their missions and roles and what types of lessons they draw from experiencing consequences such as success or defeat, impact on the military's status, how these affect its core missions, produce clashes with elites and social groups, or the extent of the public's appreciation as a result from military behaviour in operations. ${ }^{45}$ As a whole, this Special Issue is therefore meant to pave the way for further improvement

\footnotetext{
${ }^{39}$ See, for example, Muthiah Alagappa, Military Professionalism in Asia: Conceptual and Empirical Perspectives (Lanham, MD: Rowman and Littlefield, 2001); Fabrizio Battistelli, 'Peacekeeping and the postmodern soldier', Armed Forces \& Society, 23:3 (1997), pp. 467-84; Nicole Jenne, 'Civilianizing the armed forces? Peacekeeping, a traditional mission for the military', Defence Studies, 20:2 (2020), pp. 105-22; Maren Tomforde, “My pink uniform shows I am one of them”: Socio-cultural dimensions of German peacekeeping missions', in Gerhard Kümmel, Giuseppe Caforio, and Christopher Dandeker (eds), Armed Forces, Soldiers and Civil-Military Relations (Wiesbaden, Germany: VS Verlag für Sozialwissenschaften, 2009), pp. 37-57.

${ }^{40}$ Alice Hills, 'The inherent limits of military forces in policing peace operations', International Peacekeeping, 8:3 (2001), pp. 79-98; Thomas W. Britt et al. (eds), The Psychology of the Peacekeeper: Lessons from the Field (Westport, CT: Praeger, 2003); Wendy A. Broesder et al., 'Can soldiers combine swords and ploughshares? The construction of the Warrior-Peacekeeper Role Identity Survey (WPRIS)', Armed Forces \& Society, 41:3 (2015), pp. 519-40; Moskos, 'UN peacekeepers: The constabulary ethic and military professionalism'; Christopher Dandeker, 'The end of war? The use of force in the twenty-first century', in Kobi Michael (ed.), The Transformation of the World of War and Peace Support Operations (Westport, CT: Praeger, 2009), pp. 21-38; Charles C. Krulak, 'The strategic corporal: Leadership in the three block war', Marines Magazine, January (1999); Remi M. Hajjar, 'Military warriors as peacekeeper-diplomats: Building productive relationships with foreign counterparts in the contemporary military advising mission', Armed Forces \& Society, 40:4 (2014), pp. 647-72; Donna Winslow, The Canadian Airbourne Regiment in Somalia: A Socio-Cultural Inquiry (Ottawa, Canada: Canadian Government Publishing, 1997).

${ }^{41}$ Chiara Ruffa, Christopher Dandeker, and Pascal Vennesson, 'Soldiers drawn into politics? The influence of tactics in civil-military relations', Small Wars \& Insurgencies, 24:2 (2013), pp. 322-34.

${ }^{42}$ Ben-Ari and Meyyal, 'Hybrid conflicts, multiple logics, and organizational transitions'.

${ }^{43}$ Baciu, Civil-Military Relations and Global Security Governance.

${ }^{44}$ Mackubin Thomas Owen, 'Civilian control: A national crisis?', Joint Forces Quarterly, winter (1994), pp. 80-3; Don M. Snider and Miranda A. Carlton-Carew (eds), U.S. Civil-Military Relations: In Crisis or Transition? (Washington, DC: Center for Strategic \& International Studies, 1995).

${ }^{45}$ Barbara Jankowski, 'Opinion publique et armees à l'epreuve de La Guerre En Afghanistan', Etude de L'Irsem, 34 (2014), pp. 1-24.
} 
of the analytical, conceptual, and theoretical tools to understand the complex relationship between military missions and civil-military relations.

A focus on operational experience can shed light on sense-making and lesson-drawing processes at different levels of the military organisation. At the individual level, rank-and-file soldiers and tactical commanders are typically experiencing the direct consequences of new types of missions: they are in touch with the population in different types of missions, often take decisions with political consequences, suffer most casualties in missions that involve confrontations, and their skills are needed in logistical support operations. While they are assumed to obey orders, it is well known that unrest often originates among the rank-and-file because of negative experiences in missions. ${ }^{46}$ Military leaders thus have an interest in keeping lower ranks content. Yet achieving this in the context of missions that are seen as appropriate by soldiers is considerably easier than in missions that are not. For instance, soldiers are likely more willing to accept casualties in missions that are related to defending their country against external enemies than in missions that fall beyond the core tasks of their respective military. In other words, context factors and pre-existing conditions turn lived facts into different experiences. Likewise, with increasingly compressed command structures and a greater range of tasks in many missions it is more likely that the behaviour of individual servicemembers - Non-Commissioned Officers (NCOs) and junior officers - has political implications. ${ }^{47}$ This can lead to different operational experiences for military units and even individual soldiers and officers since being publicly exposed and blamed for failures can have damaging consequences for individual careers. ${ }^{48}$

The importance of individual behaviour becomes evident when mismatches between political guidelines, public expectations regarding the military's appropriate behaviour, and operational pressure on the ground affect civil-military relations. Examples for this include the order of an airstrike by a German officer in Kunduz, Afghanistan, which caused the largest number of civilian fatalities caused by the Bundeswehr since its foundation and subsequently caused a political crisis and a heated debate about the military's appropriate role. ${ }^{49}$ Mismatches between operational experiences and how missions and roles are narrated 'back home' can have negative consequences and might even be detrimental for military performance itself. Before deploying to Afghanistan, the Italian military expected to find a peacekeeping context; yet, when deployed, the military was often exposed to combat. As a result, soldiers experienced 'frame disputes' and displayed low levels of perceived cohesion, performance, and legitimacy. ${ }^{50}$ Somewhat similar mismatches can also have negative and traumatising consequences when service members return home as amply illustrated by Elin Gustavssen in her study about Norwegian veterans. ${ }^{51}$ In addition, depending on how governments deal with misbehaviour by individuals during missions ultimately also has consequences for civil-military relations: for instance, if soldiers feel treated unfairly by the public and the government for committing mistakes during operations, the civil-military gap might become larger. Taken together, mismatches between individual and collective expectations and interpretations of operational experiences may influence civil-military relations.

\footnotetext{
${ }^{46}$ Michel Louis Martin, 'Soldiers and governments in postpraetorian Africa: Cases in the Francophone area', in Giuseppe Caforio (ed.), Handbook of the Sociology of the Military (New York. NY: Springer, 2006), pp. 187-200.

${ }^{47}$ Chiara Ruffa, Christopher Dandeker, and Pascal Vennesson, 'Soldiers drawn into politics? The influence of tactics in civil-military relations', Small Wars \& Insurgencies, 24:2 (2013), pp. 322-34.

${ }^{48}$ Ofer Fridman and Beatrice Heuser, 'Deadly dilemmas: Problems of counter-insurgency and counter-terrorism in three documentaries', RUSI Journal, 158:6 (2013), pp. 92-8.

${ }^{49}$ Constantin Schüßler and Yee Kuang Heng, 'The Bundeswehr and the Kunduz air strike 4 September 2009: Germany's post-heroic moment?', European Security, 22:3 (2013), pp. 355-75.

${ }^{50}$ Chiara Ruffa and Ralph Sundberg, 'Breaking the frame: Frame disputes of war and peace', Acta Sociologica, 61:3 (2018), pp. 317-32.

${ }^{51}$ Elin Gustavsen, 'The construction of meaning among Norwegian Afghanistan veterans', International Sociology, 31:1 (2016), pp. 21-36.
} 
At a more strategic level, military leaders might draw different lessons from new operational experiences. In order to protect the institution's prestige, they might decide to punish individual soldiers or officers for wrongdoings. This obviously comes at the risk of sparking discontent among troops. If military leaders perceive that potential failure in operations threatens the institution's prestige or harm its interests, it is their choice to either adapt to new missions or to try and refocus the military's operational profile. While individual service members develop distinct interpretations about operational experiences in a specific way, we expect these to coalesce around a consolidated view, often pushed by the officer corps and which typically remains relatively stable over time. ${ }^{52}$ These consolidated interpretations fundamentally depend on how and why the armed forces make sense of their operational experiences and how they match with what they consider as their appropriate role, which is the focus of the next section.

\section{Role conception}

In order to grasp how and why operational experiences matter, we need an understanding of the military as an organisation that has agency and constantly makes sense of its lived experiences. The contributors to this Special Issue were asked to explore different possible pathways through which operational experiences shape civil-military relations. Among these, one idea stands out from their studies: how the military views its own purpose and reason of being mediates the effects of operational experiences on civil-military relations. To capture this idea, we adopt the of term role conception, which refers to the previously mentioned definition of the 'shared view, shared within one service or shared by all the services, regarding the proper purpose of the military organization and of military power in international relations'. ${ }^{53}$ Role conception thus belongs to the complex of ideational variables that have been shown to influence important aspects of the military, notably behaviour, restraint, and force posture. ${ }^{54}$ We expect the same complex of ideational factors to matter also for civil-military relations, as suggested by the literature on democratic transitions as well as earlier debates about what the military thinks it should be doing and what it actually does in the context of US civil-military relations. ${ }^{55}$

Role conceptions have varying effects and causal weight for the different authors of the issue. Based on their mapping of contemporary missions in industrialised, democratic countries, Nina Wilén and Lisa Strömbom suggest that new operational experiences may render officers more prone to see themselves as policy advocates rather than policy advisors. For Risa Brooks and Peter Michael Erickson, Anit Mukherjee, Christoph Harig and Chiara Ruffa, role conceptions have a direct impact on how the military reacts to civilian orders and whether servicemembers will resist or undermine these. For Yagil Levy as well as Nicole Jenne and Rafael Martínez, role conceptions constitute part of the background conditions against which the effects of the respective operational experiences they study play out. In the latter cases - Israel and Latin America - the military readily accepted or even pushed for new operational experiences precisely because of its particular self-image.

\footnotetext{
${ }^{52}$ For different perspectives about how the military allows for homogenous vs heterogenous views, see Joseph L. Soeters, Donna J. Winslow, and Alise Weibull, 'Military culture', in Caforio (ed.), Handbook of the Sociology of the Military, pp. 237-54.

${ }^{53}$ Vennesson et al., 'Is there a European way of war?', p. 630.

${ }^{54}$ Elizabeth Kier, Imagining War: French and British Military Doctrine between the Wars (Princeton, NJ: Princeton University Press, 1997); Jeffrey W. Legro, Cooperation Under Fire: Anglo-German Restraint During World War II (Ithaca, NY: Cornell University Press, 1995); Cornelius Friesendorf, How Western Soldiers Fight: Organizational Routines in Multinational Missions (Cambridge, UK: Cambridge University Press, 2018); Austin Long, The Soul of Armies: Counterinsurgency Doctrine and Military Culture in the US and UK (Ithaca, NY: Cornell University Press, 2016); Chiara Ruffa, Military Cultures in Peace and Stability Operations (Philadelphia, PA: University of Pennsylvania Press, 2018).

${ }^{55}$ Richard H. Kohn, 'Out of control: The crisis of civil-military relations', The National Interest, 35 (1994), pp. 3-17; Richard H. Kohn, 'First priorities in military professionalism', Orbis, 57:3 (2013), pp. 380-9; Peter D. Feaver, 'Crisis as shirking: An agency theory explanation of the souring of American civil-military relations', Armed Forces \& Society, 24:3 (1998), pp. 407-34.
} 
Role conceptions are related to neighbouring concepts such as military professionalism, military culture, and identity. The concept also captures ideas that have remained underdeveloped but have been influential nevertheless, such as Deborah Avant's 'standard way of thinking' when referring to the US Army's professional ideas of operation and purpose. ${ }^{56}$ Another take is Samuel J. Fitch's, which highlighted the importance of 'ideas' and 'belief systems' that come close to the 'shared views' that describe role conceptions:

Ideas provide the cognitive frame of reference within which boundedly rational actors including military officers - interpret the options available to them and calculate the advantages and disadvantages of alternative courses of action. Belief systems contain implicit and explicit conceptions of proper values, correct behavior, and beliefs about 'the way the world works'. Military beliefs thus structure military behavior. These beliefs do not exist in a vacuum. They reflect perceptions of the national and international context and learning from experience. $^{57}$

Others use the 'identity' of the military as supposed predictor for soldiers' skills in certain tasks and their ability to cope with new missions. However, as this identity is often referred to in terms of 'culture, attitudes, values, and motivation', 58 it remains hard to grasp empirically. In contrast to 'ideas' or 'culture', the concept of role conceptions is narrower as it is more closely related to operational experiences and consequently, more easily operationalisable since it centres on the purpose of the military organisation. Role conception, therefore, includes both how the military understands its own role towards decision-makers as well as society and towards past, present, and future missions. In the remainder of the section, we explain how role conception offers distinctive insights and advantages for empirical research.

Role conception is nested within the broader concept of military professionalism, which has largely framed debates about whether and under which conditions militaries are predisposed to interfere in politics. In Huntington's classic, highly influential understanding, a 'professional' military is one that is separate from politics and tasked with the preparation and conduct of combat operations. While this clear boundary is considered necessary to maintain the separation between the military and the centres of political power, ${ }^{59}$ a wealth of literature from military sociology and security studies has challenged both what professionalism means and whether the military as an institution can adequately be assumed to be separate from politics and as homogeneous as it was being depicted by Huntington. ${ }^{60}$ First, militaries, just like other institutions, bring together different views within the officer corps and across services, units, and specialties, which occasionally disobey and exercise control from within. ${ }^{61}$ While Huntington referred

\footnotetext{
${ }^{56}$ Deborah Avant, 'Political institutions and military effectiveness: Contemporary United States and United Kingdom', in Risa Brooks and Elizabeth Stanley (eds), Creating Military Power: The Sources of Military Effectiveness (Stanford, CA: Stanford University Press, 2007), pp. 80-105.

${ }^{57}$ Samuel J. Fitch, 'Military attitudes toward democracy in Latin America: How do we know if anything has changed?', in David Pion-Berlin (ed.), Civil-Military Relations in Latin America: New Analytical Perspectives (Chapel Hill, NC: University of North Carolina Press, 2001), pp. 61-87 (p. 84).

${ }^{58}$ Rino Bandlitz Johansen, Jon Christian Laberg, and Monica Martinussen, 'Military identity as predictor of perceived military competence and skills', Armed Forces \& Society, 40:3 (2014), pp. 521-43.

${ }^{59}$ Samuel Huntington, The Soldier and the State (Cambridge, MA: Harvard University Press, 1957).

${ }^{60}$ Risa Brooks, Michael Robinson, and Heidi Urben, 'Huntington, Janowitz, or none of the above? Conceptions of professional norms by future army officers', APSA Preprints, available at: $\{$ https://doi:10.33774/apsa-2020-6dhv6-v3\}; Tobias Böhmelt, Abel Escribà-Folch, and Ulrich Pilster, 'Pitfalls of professionalism? Military academies and coup risk', Journal of Conflict Resolution, 63:5 (2018), pp. 1111-39; Risa Brooks, 'Paradoxes of professionalism: Rethinking civil-military relations in the United States', International Security, 44:4 (2020), pp. 7-44.

${ }^{61}$ Wechsler Segal, 'The military and the family as greedy institutions'; Moskos, Williams, and Segall (eds), The Postmodern Military; Fabrizio Battistelli, 'Peacekeeping and the postmodern soldier', Armed Forces \& Society, 23:3 (1997), pp. 467-84; Yagil Levy, 'Control from within: How soldiers control the military', European Journal of International Relations, 23:1
} 
only to the officer corps when writing about military professionals, it is in fact all servicemembers, irrespective of rank, who develop a role conception, which is also shared collectively. Second, the paradigm of a 'politically sterile and neutral' military ${ }^{62}$ appears to be an ideal type rather than a reality, including in the United States. ${ }^{63}$ Furthermore, as Theo Farrell has argued, the two international norms 'shared by military professionals - norms of conventional warfare and norms of civilian supremacy ${ }^{64}$ are spatially and temporally contingent. For instance, as Jenne and Martínez remind us in this Special Issue, in Latin America professionalism has historically legitimised interventionism in politics. Officers saw running their respective country themselves as the best solution to what they perceived as impending crises civilians were unable to solve. ${ }^{65}$ Hence, the concept of Latin American military professionalism 'stimulated, rather than precluded, political action'. ${ }^{66}$ Also in other contexts like Pakistan, professionalism can be an intermediary variable of military intervention in politics. ${ }^{67}$

Taken together, the classical concept of professionalism has limited value as an analytical tool for the purpose of this Special Issue because it is at the same time too vague, too broad, and too closely modelled upon a supposed Western liberal ideal. Alternative, sociological perspectives on professionalism do not match our purpose either as they shift the focus away from the military and what it thinks it does and should be doing toward military expertise and technical knowledge. $^{68}$ Instead, the contributions to this Special Issue demonstrate how the concept of role conception and its focus on the military's perceptions and reactions can make sense of the connections between operational experiences and civil-military relations.

\section{Connecting the dots: Operational experiences, role conceptions, and civil-military relations}

Having defined civil-military relations, operational experiences, and role conception and having explained the analytical leverage of each of them, the aim of this section is to draw the different elements together into the central argument of the Special Issue. To be clear, our objective is not to provide a new theory on civil-military relations but to propose a new focus and set an agenda for studying the diverse relationship between operational experiences and interactions between society, political elites, and armed forces.

The relation between civil-military relations and role conceptions is circular and dynamic. To begin with, a specific civil-military relations equilibrium sets the context for role conceptions and operational experiences. If civilian control and defence management is strong, then it is civilian authorities who define what the military does in practice and therefore have considerable influence on role conceptions. Conversely, greater military autonomy leads to role conceptions that are comparatively less clearly defined by civilians but more so by the military's own history, narratives, and memory.

(2016), pp. 192-216; Eric Hundman and Sarah E. Parkinson, 'Rogues, degenerates, and heroes: Disobedience as politics in military organizations', European Journal of International Relations, 25:3 (2019), pp. 645-71.

${ }^{62}$ Huntington, The Soldier and the State, p. 84.

${ }^{63}$ See Brooks and Erickson, 'The sources of military dissent'.

${ }^{64}$ Theo Farrell, 'Transnational norms and military development: Constructing Ireland's professional army', European Journal of International Relations, 7:1 (2001), pp. 63-102 (p. 73).

${ }^{65}$ Frank D. McCann, 'Origins of the "new professionalism" of the Brazilian military', Journal of Interamerican Studies and World Affairs, 21:4 (1979), pp. 505-22; Alfred Stepan, 'The new professionalism of internal warfare and military role expansion', in Alfred Stepan (ed.), Authoritarian Brazil: Origins, Policies, and Future (New Haven, CT: Yale University Press, 1973), pp. 41-65.

${ }^{66}$ Frederick M. Nunn, 'An overview of the European military missions in Latin America', in Brian Loveman and Thomas M. Davies (eds), The Politics of Antipolitics: The Military in Latin America (Lanham, MD: Rowman and Littlefield, 1997), pp. 32-40 (p. 40).

${ }^{67}$ Baciu, Civil-Military Relations and Global Security Governance.

${ }^{68}$ Julia Evetts, 'Professionalism: Value and ideology', Current Sociology, 61:5-6 (2013), pp. 778-96. 
Civil-military relations and role conceptions influence both the existence and the type of effects stemming from operational experiences. First, in extreme cases role conceptions may prevent that the military assumes new tasks as demanded by civilians. Typically, we expect tensions in civil-military relations when governments seek to use the armed forces in missions that stand against the latter's role conceptions, as evident in Brooks and Erickson's contribution on the US military. It is an empirical question whether the military's eventual refusal to do something that clashes with its baseline role will be successful or whether civilians maintain the upper hand. Similar to other powerful political actors, ${ }^{69}$ the military might enter into bargaining processes in which they make demands in exchange for carrying out undesired tasks. Depending on the outcome of the political bargain, the civil-military relations equilibrium is altered as the armed forces might change their predisposition to interfere in political decision-making processes and ultimately be able to gain greater political influence. ${ }^{70}$

Second, once the military engages in new operational experiences, role conceptions mediate how these are interpreted, lived, and made sense of. A new mission might be carried out successfully in the sense that it accomplishes its objectives and yet, if it contradicts what the military believes to be its proper purpose, the mission might not actually be experienced as a success by the institution. Conversely, failure in new missions might reinforce dismissive attitudes towards following demands to repeat such operations. Apart from issues of success or failure, militaries might seize the opportunities arising from new operational experiences: for instance, disaster relief operations potentially lead to greater public appreciation and other types of operations, such as UN peacekeeping, can increase the military's bargaining power in pushing for renewal of military equipment. Still, changes in role conceptions due to operational experiences are not a given. Militaries might succeed in steering civilian governments away from insisting on demands for unwanted operations, or governments themselves conclude that military deployments in certain circumstances must remain exceptional. Only if new and eventually even undesired missions - understood as 'specific tasks" ${ }^{71}$ - are carried out to such an extent that they become part of the military's role - understood as 'broad and enduring purpose ${ }^{72}$ armed forces might slowly change their role conceptions accordingly. Such changes in role conceptions may manifest themselves in organisational reorientations that aim to prepare dedicated military units or the military as a whole for these new missions. For instance, this includes modified military education and training, reformulations of military doctrine, or budget realignments with the goal of purchasing appropriate equipment. Such change may entail role expansion, as in the case of the Israeli military that increased its range of tasks and function through its involvement in the response to the COVID-19 pandemic by taking on roles as epidemiologists, among others. ${ }^{73}$ Other examples include the Brazilian military, which reacted to an increasing demand for public security operations by drafting a doctrine and creating a specialised training centre for 'Guaranteeing Law and Order' operations. ${ }^{74}$ Changes in role conceptions can also include exclusively non-material modifications of the military's orientation. In its most consequential form for civil-military relations, this is related to military leaders' predisposition to interfere in politics. More indirectly, shifts in role conceptions may lead to forms of organisational decoupling, in

\footnotetext{
${ }^{69}$ Brooks, 'Integrating the civil-military relations subfield', p. 203.

${ }^{70}$ Christoph Harig and Chiara Ruffa, 'Knocking on the barracks' door: How role conceptions shape the military's reactions to political demands', European Journal of International Security, this Special Issue.

${ }^{71}$ Paul Shemella, 'The spectrum of roles and missions of the armed forces', in Thomas C. Bruneau and Scott D. Tollefson (eds), Who Guards the Guardians and How: Democratic Civil-Military Relations (Austin, TX: University of Texas Press, 2006), pp. 122-44 (p. 123).

${ }^{72}$ Shemella, 'The spectrum of roles and missions of the armed forces', p. 123.

${ }^{73}$ Levy, 'The people's army "enemising" the people'.

${ }^{74}$ Christoph Harig, 'Soldiers in police roles', Policing and Society, 30:9 (2020), pp. 1097-114.
} 
which parts of the military adapt to the shift and others do not. Decoupling could lead to a decline in cohesion and accountability of the military towards civilian authorities. ${ }^{75}$

With a change in role conceptions, the military recalibrates its positioning $v i s$ - $\grave{a}$-vis civilians, both authorities and society at large, since the civilian 'other' is key in the construction of military identity, which in turn encapsulates views about its purpose. ${ }^{76}$ Militaries might adapt to new operational challenges and modify their role conceptions accordingly, but still might demand benefits in return or feel empowered to become involved in decision-making processes regarding the circumstances of their deployment. When armed forces change their role conceptions and thus develop new operational capabilities, civilians are likely to reposition themselves in relation to a military with different conceptions and missions, thus resulting in a new civil-military relations equilibrium. In extreme cases, this can be harmful for civil-military relations if civilian governments make themselves dependent upon the military fulfilling essential state services. Hence, they increase the armed forces' bargaining power, which commanders can then use to extract concessions.

\section{Perspectives on operational experiences and civil-military relations: The contributions}

The contributions to the Special Issue bring together a plurality of theoretical, methodological, and empirical perspectives to shed light on the dynamics between operational experiences, role conceptions, and civil-military relations. While some take a comprehensive look at civil-military relations, others delve into specific parts of the tripartite relation between the military, civilian elites, and society. In the following, we provide an overview of the individual studies and how they deal with the operational experiences of armed forces and their consequences for role conceptions and civil-military relations.

Nina Wilén and Lisa Strömbom start by mapping contemporary military roles and tasks in industrialised democracies. As the authors note, there is little academic and practical consensus about the core roles of military institutions in democratic societies. The fact that terms such as 'mission', 'role', and 'task' are often used sloppily further adds to the confusion. Relying on the understanding that roles are social constructions about the 'broad and enduring purpose' of the military, ${ }^{77}$ the authors identify three core roles based on the analysis of defence policy documents of the 37 member countries of the Organization of Economic Cooperation and Development (OECD) in combination with an extensive review of academic texts: (collective) defence, collective security, and aid to the nation. These policy documents can be assumed to reflect the collective views by the military, civilian authorities and society, given that the OECD countries are, by way of membership admission, democracies. Each of the roles has a number of subroles and tasks. Wilén and Strömbom argue that during the past decade, new operational experiences have brought the military closer to society due to its internal and more visible tasks while, at the same time, the relation has grown more distant due to the end of conscription in many states. Yet altogether, the new tasks and organisational changes have increased both trust in the military and its popularity. While this comes with potential risks for democratic civilmilitary relations, the authors highlight that militaries have been forced to adapt to a rapidly changing security environment and popular demands, which has constrained their organisational power. The conceptual article by Wilén and Strömbom is followed by five articles that delve deep into either single case studies or comparative designs.

Turning to the contemporary United States, Risa Brooks and Peter Michael Erickson explore the military's reluctance to engage in what can be considered 'unconventional' missions in the context of its usual operational profile. The authors ask why and how the US military leadership

\footnotetext{
${ }^{75}$ Ben-Ari and Eran-Jona, 'Hybrid conflicts, multiple logics, and organizational transitions'.

${ }^{76}$ Celso Castro, 'Anthropological methods and the military', in Helena Carreiras and Celso Castro (eds), Qualitative Methods in Military Studies: Research Experiences and Challenges (London, UK: Routledge, 2013), pp. 8-16.

${ }^{77}$ Shemella, 'The spectrum of roles and missions of the armed forces', pp. 123-4.
} 
contested political decisions over different missions and analyse implications for civil-military relations. In a detailed analysis of military resistance to involvement in humanitarian interventions in the 1990s, the 'War on Drugs' in the 1980s, and the expansion of the counterinsurgency campaign in Afghanistan, Brooks and Erickson identify several sources of dissent as well as tactics used by the military for exercising political pressure. Operational experiences, in particular failures in warfare, have shaped the role conceptions of the military and are one among several interlinked sources of military dissent. Their argument underlines the circular relationship between operational experiences, role conceptions and civil-military dynamics. Role conceptions were significantly shaped by operational experiences that were brought about by political choices. In turn, these experiences were a major factor for motivating military leaders to contest decisions made by democratically elected governments. The contestation by military leaders then changed civilmilitary dynamics, as it altered the decision-making process regarding military operations and constrained politicians in their choices.

Further analysing how military missions shape civil-military relations, Nicole Jenne and Rafael Martínez adopt a broader conceptualisation of civil-military relations in democracy. They argue that conceiving of civil-military relations in terms of democratic governance across different sectors provides additional insights into how the military's use in different functions affects their position within the state and society. The authors demonstrate how Latin American governments have used the military as a wildcard for a wide range of tasks whenever civilian capacities have been of short supply, including urban and border patrols, literacy campaigns and to collect garbage, among many others. Such widespread use of the military, according to Jenne and Martínez, has maintained alive long-standing role conceptions of the military as the ultimate guardian of the state and la patria with negative effects for civil-military relations. From a democratic governance point of view, falling back on the military for multiple internal tasks challenged the rule of law in several cases, led to a lower quality of basic public services democratic states ought to provide, including defence, and perpetuated undemocratic tendencies.

Christoph Harig and Chiara Ruffa explore the phenomenon of democratically elected governments that are 'pulling' the military into potentially problematic roles. Their conceptual contribution unpacks the civil-military dynamics at different stages of two types of 'pulling': political pulling and operational pulling. In political pulling, the government asks the military to become involved in partisan conflicts, for instance in disputes between government branches or in large-scale protests. They argue that the military's reactions to such demands fundamentally depends on how much they value non-partisanship in their role conception. Operational pulling is more subtle as it implies politicians drawing the military into missions with blurry political connotations. With case studies of operational pulling into public security missions in France and Brazil, the authors show how operational pulling can be a crucial factor for changes in military role conceptions. In both cases, military leaders made political demands in exchange for providing public security. As a result, the French military's visible political involvement is the highest in decades. In Brazil, operational pulling made the military increasingly confident to make political demands and thus contributed to the generals' influential role in the government of current president Jair Bolsonaro.

Yagil Levy explores the case of the Israel Defense Forces (IDF), which were amply and extensively deployed to combat the coronavirus during 2020-1. Ostensibly, the military's engagement is instrumental to fighting the pandemic due to its resources and hierarchical discipline, and especially given its centrality in Israel. Assuming that military deployment can be seen as part of the 'securitisation of coronavirus', as a policy regime, Levy argues that securitisation augments the endeavour to use state-centralised mechanisms to handle the crisis, with the resulting deployment of the military. In turn, the deployment, constitutive of the discourse of securitisation, further legitimises securitisation. Levy argues that the IDF's political bargaining power did not necessarily increase as a result of its involvement in Israel's Covid response. Still, the IDF made its support conditional on financial support and more resources. Moreover, securitisation 
has challenged Israel's deliberative democracy as it narrowed the scope of the debate about the handling of the pandemic, thus privileging short-term security measures over longer-term social and economic considerations. The IDF being involved is a further case of clearly established civilian control leading to militarisation.

Anit Mukherjee examines the effects of combat casualties on role conceptions and democratic civil-military relations. In such context, Mukherjee argues that militaries which incur combat casualties gain a stronger hand in the civil-military equilibrium. This is because casualties affect domestic political opinion and give prominence to the views expressed by military officials. Civilians are then more deferential to professional military advice. In turn, the military obtains considerable operational freedom, and can pick and choose missions which they find desirable. Based on the case of India, Mukherjee finds that a military's role conception, an important determinant of military missions, is shaped most prominently by its combat experience. Militaries sustaining casualties obtain leverage vis- $\grave{a}$-vis civilians and based on their institutional preference, they either prioritise or avoid non-traditional missions. The study illuminates the mechanism through which operational experiences and casualties affect civil-military relations and role conceptions, which partly accounts for the persistence of the combat role conception among militaries across the globe.

\section{Conclusion and avenues for future research}

This Special Issue seeks to develop an analytical toolkit for studying the connections between operational experiences and civil-military relations. Providing a set of conceptual, theoretical, and empirical investigations of the relationship between military missions and the military's place in society and politics, the research collection follows Brooks' call to go beyond simplistic notions of civilian control and military autonomy that obscure the military's political role in everyday politics but instead recognise that 'the military is akin to other powerful constituencies in the state in how it derives power and impacts distributional and policy outcomes'. ${ }^{78}$

To a large extent, the theoretical underpinnings of civil-military relations scholarship were developed upon standards that either derived from case studies of militaries from industrialised democracies or focused on very visible military interventions in politics in the form of coups. In the approach presented here, we problematise some recurring assumptions such as the depiction of combat operations as the only and most important 'conventional mission' of the armed forces, the overemphasis on the geographical locus of missions while neglecting closer analysis of what militaries are actually doing in a given operation, as well as the idea that undemocratic civilmilitary relations are the necessary consequence of military leaders pushing for greater influence. The prevailing focus on the institutional dimension of civilian control, particularly in research on transitional and consolidating democracies, cannot account for instances in which democratic governments draw their armed forces into roles that have the potential to upend democratic politics. As the contributions of Brooks and Erickson, Jenne and Martínez, Levy, as well as Harig and Ruffa show, there are many ways in which politicians deliberately choose to increase the military's social and political roles. In these instances, it is the existence of institutions of civilian control that are the very source for an increase in the military's political power if politicians pull the military into new political or operational roles. Whether they succeed depends essentially on the military's reaction to political demands.

What could drive a military's reaction that can be so important for the future of civil-military relations? The contributions to the Special Issue demonstrate that the operational profile and the respective experiences in missions are crucial for understanding military leaders' willingness to become involved in politics. All else being equal, role conceptions can even be a decisive factor: if institutions for civilian control are in place and democratic governments order the military to

\footnotetext{
${ }^{78}$ Brooks, 'Integrating the civil-military relations subfield', p. 391.
} 
become involved in partisan disputes, it is up to military leaders to decide whether to obey critical orders or to find ways to extricate themselves from demands that threaten the military's self-understanding. How military commanders solve such a dilemma fundamentally depends on their role conception. Although the case studies in this Special Issue represent democracies at different stages of consolidation, we expect that the circular relationship between the military's operational experiences and civil-military relations equally exists in authoritarian contexts. Further research on the effects of missions on civilian control in authoritarian states may build on this Special Issue to probe the relevance of role conceptions and their consequences for governance across different regime types.

To further the research agenda on operational experience, role conceptions, and the military's role in routine politics, we identify six avenues for future study. First, more conceptual work is needed to systematically categorise and classify different kinds of missions other than combat, particularly in relation to its potential implications on role conceptions and civil-military relations. ${ }^{79}$ After all, the operational experience in highly different tasks, for instance in disaster relief as opposed to public security, varies significantly. The same applies to the military's perceptions regarding success or failure in these kinds of operations. Still, the current state of civil-military relations in a given country might trigger different consequences for role conceptions. If armed forces have not internalised an acceptance of civilian supremacy and rather see themselves as guardians of the nation, even seemingly harmless deployments such as disaster relief can lead to greater political intrusion by the military. For instance, military leaders could become more prone to overthrowing governments they consider to be in some way responsible for the disaster. It is more likely, though, that military leaders seek to increase their political influence in less overt manners. In this regard, it would be worthwhile to explore intra-military deliberations as well as ways in which armed forces seek to negotiate role conceptions and their position in society. It would be particularly interesting to explore how retired military officers often act as unofficial spokespersons for military institutions, which in many countries are legally banned from openly participating in political debates.

Second, future studies may analyse how different factors other than operational experiences lead to change in role conception, among them strategic, economic, and technological change. The end of the Cold War gives us an example for changes in role conceptions that were triggered by a modification of perceived threats in many European countries. Likewise, these studies may explore the possibilities of civilians to engineer change in role conceptions. This may be done by redirecting the military's missions, shifting the military education system, or by changing the social composition of the officer corps.

Third, there are potential benefits in delving deeper into to the ideational complex where role conceptions, professionalism, securitisation, culture, and other concepts overlap to examine how these interact and constitute one another. ${ }^{80}$ One could systematically explore how distinct role conceptions may emerge within a particular military culture. The French army culture, for instance, traditionally revolved around staying out of politics as much as possible. Within that culture, the role conception of the French military deployed in expeditionary operations emerged and consolidated because it 'made sense' and was coherent.

Fourth, there is still a need for more fine-grained mechanisms exploring variation in civilmilitary relations over time. Civil-military equilibria are inertial but not static and we still do not quite know how they change. Alterations in civil-military equilibria may occur when civilian authorities redirect the military to other roles, or when military leaders actively seek to shape politics. However, shifts in role conceptions and civil-military relations are also possible due to

\footnotetext{
${ }^{79}$ Lise Howard, 'Peacekeeping is not counterinsurgency', International Peacekeeping, 26:5 (2019), pp. 545-8.

${ }^{80}$ For an interesting discussion on cultural complexes, see Megan MacKenzie, Eda Gunaydin, and Umeya Chaudhuri, 'Illicit military behavior as exceptional and inevitable: Media coverage of military sexual violence and the "bad apples" paradox', International Studies Quarterly, 64:1 (2020), pp. 45-56.
} 
generational change among the officer corps and attitudinal developments in society. Such phenomena occur without any deliberate actions being taken and are hard to grasp with institutionalist perspectives on civil-military relations. Therefore, closer analysis of the social composition of armed forces and attitudinal commonalities and differences to the general population could provide fruitful avenues for further research on endogenous military change processes. Fifth, future research should also investigate the processes through which a consolidated and shared interpretation of role conceptions and of operational experiences emerge. Of particular promise for theory development are distinct role conception interpretations within the same military and the examination of what changes and shifts may entail for civil-military relations. For instance, the Swedish military has had, since the early 1990s, two services with different role conceptions: a navy with a domestic defence role and an army with an expeditionary focus. With the recently announced return to domestic territorial defence, the army will have to shift dramatically in role conceptions, while the navy will only have to make minor adjustments. The officer corps in the two services are currently positioning themselves differently towards its civilian principals - one adapting, the other pushing for more autonomy - with distinct consequences for civil-military relations at least in the short term.

Sixth and last, further research could explore how militaries across the world expand their role conceptions to include tasks and functions from other professions of experts they are co-operating with, such as epidemiologists in the case of Israel, or police in the case of Brazil and France. Pushing this line of research further is crucial to ultimately understand what kind of organisation a state military is and how it navigates the civil-military environment it is part of.

Acknowledgements. The authors contributed equally to this article. They wish to thank Risa Brooks, Yagil Levy, Lindsay Cohn, Muhammad Haripin, Anit Mukherjee, Pascal Vennesson, Nina Wilén, and the unicorn federal union for their helpful feedback on earlier versions of the manuscript. Chiara Ruffa gratefully acknowledges financial support from the Royal Swedish Academy of History, Letters and Antiquities. Nicole Jenne acknowledges financial support from the Chilean Agencia Nacional de Investigación y Desarrollo (ANID), Fondecyt Regular No. 1210067 (2021). Open Access funding was kindly provided by Technische Universität Braunschweig.

Christoph Harig is Research Fellow at the Institute of International Relations, Technische Universität Braunschweig, Germany.

Nicole Jenne is Associate Professor at the Institute of Political Science, Pontificia Universidad Católica de Chile, Santiago, Chile.

Chiara Ruffa is Associate Professor and Academy Fellow at the Swedish Defence University.

Cite this article: Harig, C., Jenne, N., Ruffa, C. 2022. Operational experiences, military role conceptions, and their influence on civil-military relations. European Journal of International Security 7, 1-17. https://doi.org/10.1017/eis.2021.29 